\title{
GROUNDWATER POTENTIAL MAPPING IN IKORODU, LAGOS STATE, NIGERIA, USING MULTI-CRITERIA ANALYSIS ANDHYDROGEOPHYSICS
}

\author{
E. E. Epuh'1, *, M. J. Orji², H. A. Iyoyojie ${ }^{3}$ and O. E. Daramola4 \\ $\mathbf{1 , 2 , 3 , 4}$, DEPARTMENT OF SURVEYING AND GEOINFORMATICS, UNIVERSITY OF LAGOS, LAGOS STATE, NIGERIA \\ E-mail addresses: ${ }^{1}$ eeepuh@yahoo.com, ${ }^{2}$ orjimichael23@yahoo.com, ${ }^{3}$ harryiyo@yahoo.co.uk, \\ 4 olagoke.daramola@gmail.com
}

\begin{abstract}
The assessment of the potential groundwater recharge area is extremely important for water quality protection and proper management of ground water systems. The objective of this study was to evaluate systematic groundwater studies using the integration of remote sensing and geographic information systems (GIS) and hydrogeophysics as a tool to identify groundwater potential areas in Ikorodu, Lagos. In this study, various thematic maps (layers) derived from satellite image classification such as: Land use/ Land cover map, soil map, rainfall map, geological map, slope map derived from SRTM Digital Elevation Model, lineament density map obtained as a result if lineament analysis of the principal component of the image, were all integrated using the weighted overlay tool in the spatial analyst toolbox of ArcGIS 10.5. Ranks and weights of classes and sub-classes of the thematic layers were assigned based on their influences on groundwater occurrence. The vertical electrical sounding data obtained from the study area were used to validate the results of the groundwater potential map and also determine the areas with brackish water, saline water and freshwater and the most probable drillable depth for exploration. The results show that the groundwater potential zones of the study area could be classified into five zones with the following percentage for spatial distribution: "very high" potential zone (0.6\%), "high" (4.2\%), "moderate" (15.8\%), "low" $71.7 \%$ and very low potential zone (7.7\%). The South-Western region of Ikorodu, close to Oriwu has the highest concentration of groundwater. Imota is characterized with Moderate and Low ground water potentials. From the query results, the aquiferous layers were identified, their yield and potentials determined and the depths to which boreholes can be sunk for the drilling of fresh water were found to be between $20 \mathrm{~m}$ and $120 \mathrm{~m}$ respectively.
\end{abstract}

Keywords: Groundwater, Remote sensing, GIS, Hydrogeophysics.

\section{INTRODUCTION}

Groundwater has become immensely important for the different water supply purposes in urban and rural areas of both the developed and developing countries [1]. However, groundwater exploration in hard rock terrain is a very challenging and difficult task, if the promising groundwater zones are associated with fractured and fissured media [2]. In such an environment, the groundwater potentiality depends mainly on the thickness of the weathered/ fractured layer overlying the basement. Groundwater can be explored using different methods. The four major groundwater exploration methods are the areal method, surface method, subsurface method and esoteric methods. Among these methods, esoteric method is not based on science, mostly based on traditional indicators. Each of the above listed groundwater exploration methods have different submethods under them. The integration of remote sensing, Geographic information system and hydrogeophysical survey incorporates both the areal and the surface method of groundwater exploration. This integrated approach has shown to be very important for both groundwater resource mapping

* Corresponding author, tel: +234 8023228354 
and water quality evaluations. Its application for groundwater exploration purposes has increased over the last few years due to the rapid advances in computer packages and associated numerical modeling solutions [2]. Groundwater exploration entails delineation and mapping of different lithological, structural and geomorphological units. Satellite based remote sensing data facilitate the preparation of lithological, structural, and geomorphological maps, especially at a regional scale. Geomorphological investigations include the delineation and mapping of various landform and drainage characteristics that could have a direct control on the occurrence and flow of groundwater. The application of geomorphology in groundwater mapping activities significantly contribute in deciphering areas of groundwater recharge and their potential for groundwater development [3]. These activities include (a) the use of digital elevation models (DEM) for landform classification (b) Soil maps and their permeability to determine the water holding capacity of an area (c ) Lineaments maps as indicators of sub-surface faults and fractures that influence the occurrence of ground water actin as reservoirs and canals. The lineament density of an area greatly exposes the ground water potential of the area, since the presence of lineaments mostly indicate permeable zones. Areas with high lineament density have high ground water potentials. Various attempts have been made in the generation of different thematic maps for the delineation of groundwater potential zones in different parts of the country $[4,5]$.

Many researchers have tried to quantify groundwater resources in hard rocks, based on linear features in various types of maps and remote sensing imagery $[6,7,8,9,10]$.

In this study, the following thematic maps: soil, rainfall, slope, geological map, lineament, landuse and land cover maps were analyzed as well as other collateral information with necessary ground check helps in generating the base-line information for ground water prospecting. Groundwater is an important source of water supply in Lagos State. The people of Ikorodu local government area depend on groundwater as a major source of water supply for consumption. Despite the provision of potable water through the state government the populace still depends on wells and boreholes for domestic water supply. More also, the state government public water facility is not in use due to lack of maintenance value and this has brought about acute water scarcity. There are few scattered boreholes within the environs which give room for more to be installed to curb water scarcity. This prompted the need for investigating groundwater exploration using GIS, remote sensing and hydrogeophysics techniques in the study area.

\section{STUDY AREA}

\subsection{Description of the Study Area}

Ikorodu is a city and local government Area in Lagos state, Nigeria, located along Lagos lagoon, it shares a boundary with Ogun state. Ikorodu had an estimated population of 689,045 based on 2006 census. Geographically located between Longitudes $6^{\circ} 31^{\prime} N$ and $6^{\circ} 41^{\prime} N$ and Latitude $3^{\circ} 26^{\prime} E$ and $3^{\circ} 42^{\prime} E$. Figure 1 shows the map of the study area.

\subsection{Hydrogeology of Lagos Metropolis}

Lagos state is principally a sedimentary region located within the western part of Nigeria; a zone of coastal creek and lagoon. The area is also developed by barrier beaches associated with sand deposition [11]. The sub-surface geology reveals two basic lithologies; clay and sand deposits. These deposits may be interbedded in places with vegetable remains and peak. The water bearing strata of Lagos state consists of sand, gravel or admixtures from fine through medium to coarse sand and gravel [12]. There are four main aquiferous units that are being tapped for water supply within Lagos metropolis. The first aquifer extends from ground level to roughly $12 \mathrm{~m}$ below ground. It consists of alternation layers of clay and sand. This upper aquifer is prone to contamination because of its limited depth. The second aquifer is encountered between $20 \mathrm{~m}$ and $100 \mathrm{~m}$ below sea level and it can be found around Ikeja and Ojota axis. This aquifer is of greater importance for water supply purposes throughout Lagos metropolis [13]. The third aquifer in the central part of Lagos has a depth ranging from $130 \mathrm{~m}-160 \mathrm{~m}$ below the sea level and the fourth aquifer is located at an elevation of approximately $450 \mathrm{~m}$ below sea level. It is separated from the third aquifer by a rather thick layer of shale of the Ewekoro formation. Only a few boreholes tap water from this aquifer [13]. The population of Lagos, estimated at 3.6 million in 1980, is presently (2019) estimated at 18 million and is thought to be increasing at a rate of 833 persons per day. Until fairly recently, surface water was the major source of water supply for domestic and industrial 
uses with a little supplement from hand-dug wells by individual concerns. Increased awareness of the large stock of available water underground has led to the conception and execution of development plans based entirely on groundwater. The execution of some of these plans (mostly in recent times) has generated new information on sub-surface geology and aquifer characteristics below Lagos metropolis.

\section{MATERIALS AND METHODS}

\subsection{Datasets}

\subsubsection{Remote sensing and GIS}

Table 1 shows the acquired satellite images used for the study and other secondary data from relevant agencies.

\subsubsection{Hydrogeophysics}

The Hydrogeophysics data were Vertical Electrical Sounding (VES) obtained using the Schlumberger array of the four point electrode spacing using a Terrameter. The data contains fifteen (15) stations obtained within the study area.

The purpose of VES is to investigate the changes in subsurface formation resistivity with depth. It shows apparent resistivity (pa) variation with depth with sample use of electric sounding which provides an estimate of the resistivities of the first and last layers and indicates the relative resistivities of intermediate layers. Hence the method is useful in determining and delineation of the aquifer depth.

\subsection{Methodology}

\subsubsection{Generation of Thematic layers}

The Landsat satellite image, path and row 191/55 was used. In applying the weighted overlay fusion analysis, the sub-classes of each thematic layer were ranked and weights were assigned based on influence on groundwater. Geology was assigned $31 \%$, Rainfall, 24\%, Soil,17\%, Lineament, 13\%, Slope, $10 \%$, and Land Cover, $4 \%$. Figure 2 shows the methodology flow chart for the production of the groundwater potential zonation map.

The evaluation of ground water prospect for each zone in the output is based on the added values of scores of various themes as described in the equation 1.

$$
\begin{aligned}
G W P I=G s G w & +R s R w+S s S w+L s L w+S L s S L w \\
& +L U s L U w
\end{aligned}
$$

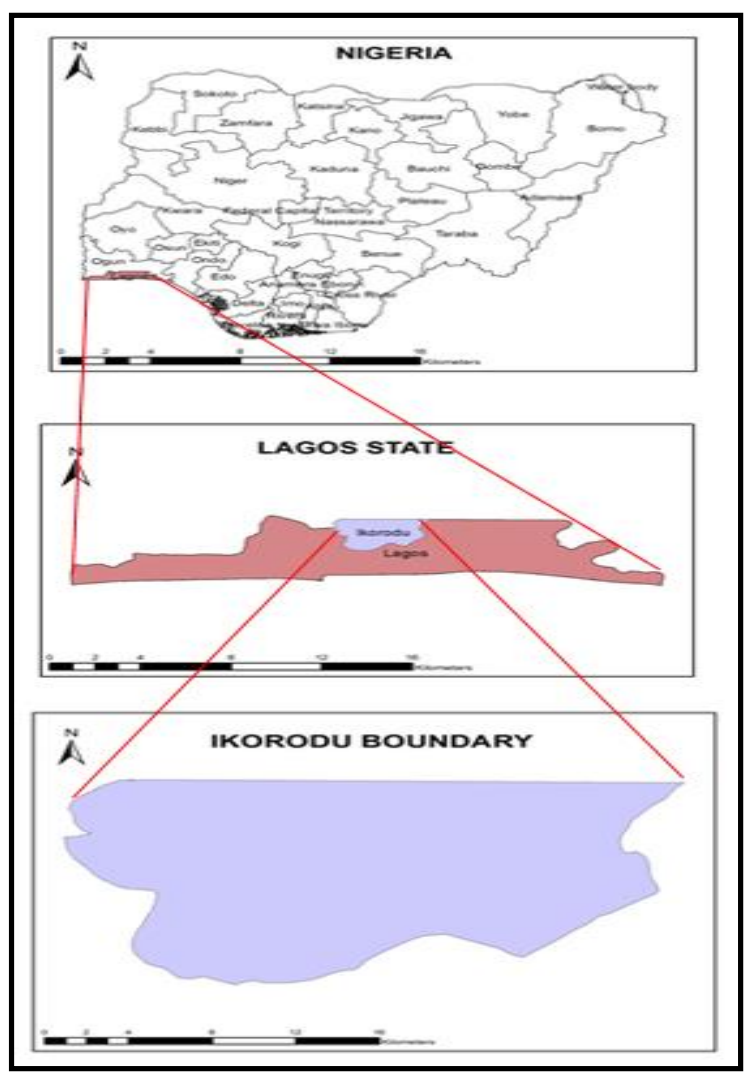

Fig. 1: Map of Study Area

Table 1: Data sets for the study.

\begin{tabular}{|l|l|l|l|}
\hline S/no & Remote Sensing Data & Data Source & Year \\
\hline 1 & SRTM/DEM & Global Land Cover Facility (GLCF) & 2018 \\
\hline 2 & $\begin{array}{l}\text { Satellite imagery (Landsat-8 ETM) } \\
\text { Landcover/use }\end{array}$ & $\begin{array}{l}\text { USGS Earth Explorer } \\
\text { Soil Survey Division of the Federal Department of } \\
\text { Agricultural land Resources (FDALR) Kaduna in } \\
1990 .\end{array}$ & 2018 \\
\hline 3 & Soil Map of Nigeria & Nigeria Geological Survey Agency (NGSA) & 1990 \\
\hline 4 & Geology map of Nigeria & Tropical Rainfall Measuring Mission (TRMM) & 2017 \\
\hline 5 & Rainfall data & Nigerian Satellite & 2018 \\
\hline 6 & Lineament &
\end{tabular}


Where, GWPI = Ground Water Potential Index, $\mathrm{SL}=$ Slope, $\mathrm{G}=$ Geomorphology, L= Lineament density, $\mathrm{LU}=$ Landuse/landcover, $\mathrm{S}=$ Soil, $\mathrm{R}=$ Rainfall, $\mathrm{s}=$ Score of the feature in the theme and $w=$ weight of the theme.

The range of GWPI values (score value) were divided into five classes (called zones) and the GWPI of different polygons falling under different range were grouped into one class. Thus, the entire study area was qualitatively divided into five ground water potential zones namely; very high potential, high potential, moderate, low potential and very low potential for groundwater.

\subsubsection{Hydrogeophysics (VES Interpretation, Scaling and Gridding of Geoelectric Sections)}

The VES Curves were quantitatively interpreted by partial curve matching using two-layer model curves and the corresponding auxiliary curves. multi-layered field curves were matched segment by segment starting from the small electrode spacing. The theoretical VES curves were generated from partial curve matching interpretation results (layer, thickness and resistivities) using a computer programme based on the inputted data. The field curves were then compared with the computer-generated curves and a good fit was obtained between the field and computer - generated curve. The scaling and gridding of the geoelectric section involves the construction of a digital file suitable for aquifer reservoir mapping and gridding. The geoelectric sections were digitized with respect to their differential lithostratigraphic thickness. The modules in the reservoir scaling were designed to produce chains of cells for visual representation of beds, bed sets, lamina, and lamina sets in a two dimensional outlook. Each lithologic unit was assigned its own interpreted geologic parameters and this process was carried out in all the fifteen geoelectric sections used in the research. The extended entity relational model was utilized in the creation of the Hydrogeophysics database.

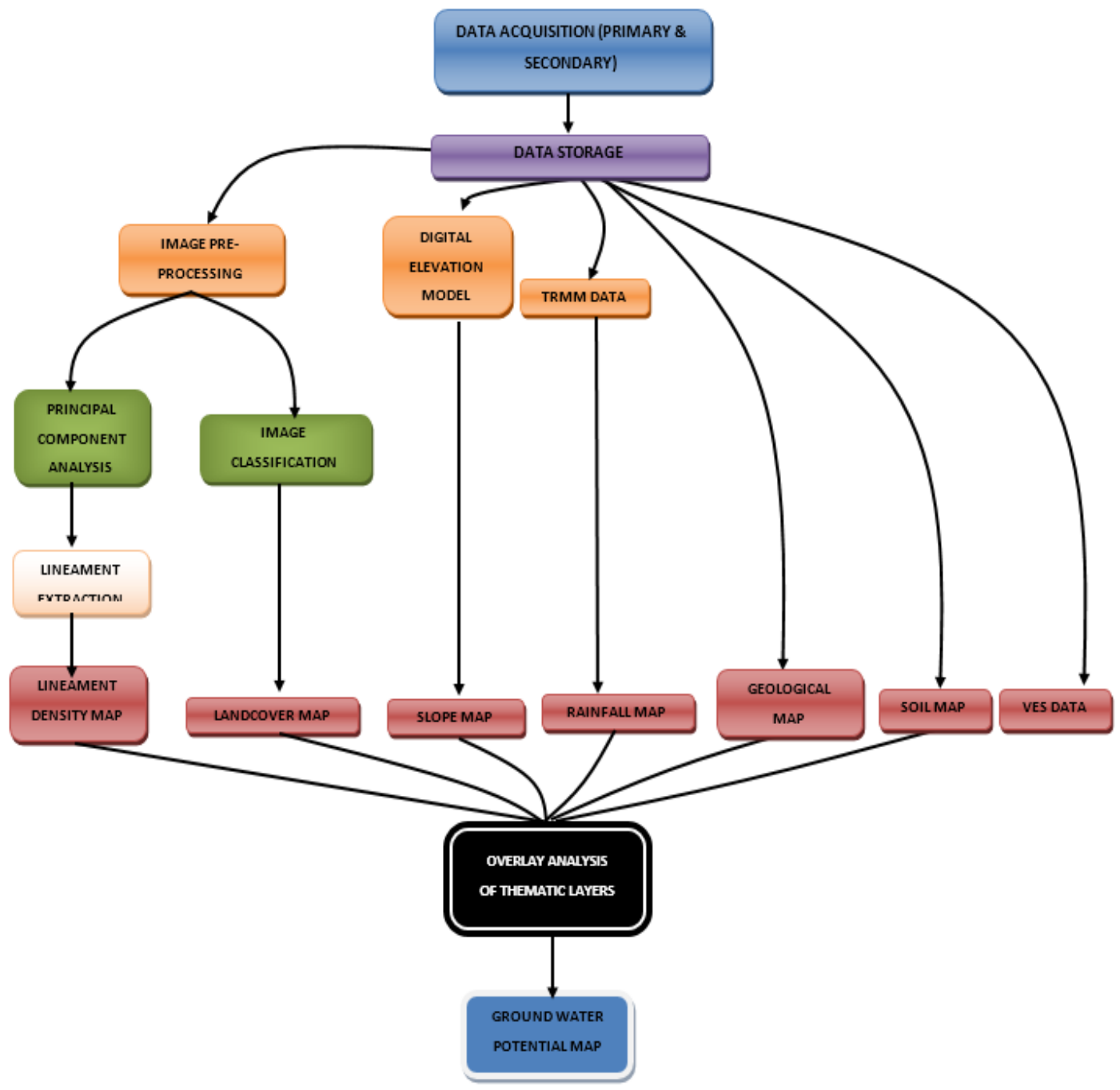

Fig. 2: The Methodology Flowchart 


\section{RESULTS AND DISCUSSION}

\subsection{Results}

\subsubsection{Soil Map}

The analysis of the soil types shows that the study area is predominantly covered by two main soil types namely; Brownish-black saline mangrove soils and Reddish Friable Porous Sands to Sandy Clays. Based on the influence of groundwater occurrence, areas with Brownish-black saline mangrove soils have high ground water potentials than areas with Reddish Friable Porous Sands to Sandy Clays. The soil map of the area drawn in a scale of $1: 100,000$ is shown in Figure 3.

\subsubsection{Slope Map}

The slope map of the study area was derived from the Digital Elevation Model extracted from the SRTM DEM using the slope tool located in the spatial analyst arc toolbox. The map is plotted at a scale of 1 : 100,000 (Figure 4). Slope is one of the most essential terrain derivatives used in expressing the steepness from ground surface, providing information on the nature of geologic and geodynamic processes operating at the regional scale. The map shows two categories: low slope in the southwest part and high slope in over $90 \%$ of the area (Figure 4).

\subsubsection{Rainfall Map}

The rainfall data was classified into three classes via low, moderate and high with the southern part having the high rainfall class (Figure 5 ). The rainfall map drawn in a scale of $1: 100,000$

\subsubsection{Geological Map}

Two main geology types were found in the study area (Figure 6). They are the Alluvial and Coastal plain sand. Alluvial is the depositional structure formed by running water hence highly good for ground water prospect. Although the area is highly dominated by coastal plains, coastal plain sands have been found to be highly permeable for ground water flow.

\subsubsection{Lineament Map}

Lineaments are indicators of sub-surface faults and fractures that influence the occurrence of ground water acting as reservoirs and canals. Lineament density of an area greatly exposes the ground water potential of the area, since the presence of lineaments mostly indicate permeable zones. Areas with high lineament density are anticipated to having high ground water potentials. Figure $7 a$ shows the lineaments extracted from the Landsat 8 covering the area.
Figure 7b shows the lineament density map. The Lineament density map has three (3) classes - Poor, Good and Very Good based on distance from the lineaments. These classes are evenly distributed through the study area.

\subsubsection{Landcover/land use Map}

The land use/land cover classification result shows that the study area, Ikorodu metropolis is covered by five classes namely; built-up, bareland, vegetation and waterbody as shown in Figures $8 \mathrm{a}$ and $8 \mathrm{~b}$. The surface covered by vegetation such as forest and agriculture trap and hold the water in root of plants whereas the built-up and rocky land cover classes affect the recharge of groundwater by increasing rainfall run-off.

\subsubsection{Groundwater Potentials of Ikorodu}

The ground water potential zones were obtained by overlaying all the six thematic layers using the weighted overlay technique embedded in the Weighted overlay tool in the spatial analysis toolbox in ArcGIS 10.5. Integration of thematic layers and modeling through GIS yielded the groundwater potential mapping (Figure 9) which was classified as very high potential, high potential, moderate potential, low potential and very low potential. Pie and bar Chart depicting the Groundwater Potential distribution of the study area are shown in Figures $10 \mathrm{a}$ and $10 \mathrm{~b}$ respectively.

\subsubsection{Digitized Geoelectrical Sections and Queries}

The VES points were all located within the low groundwater potential of the study area as shown in Figure 11.

The queries were carried out on the VES geoelectric sections and basemap to determine the VES locations with various groundwater conditions. The queries show the location, depth, layer thickness and coordinates. The identified points of the queries on the geoelectric section and basemap are shown in yellow colour. The queries include the following:

1. The location and depth for Brackish water (Figures $12 a, b)$

2. The location and depth for Fresh water (Figures 13a, b)

3. The location and depth for Saline water (Figures 14a, b)

The Drillable locations in the study area (Figures 15a, b) 

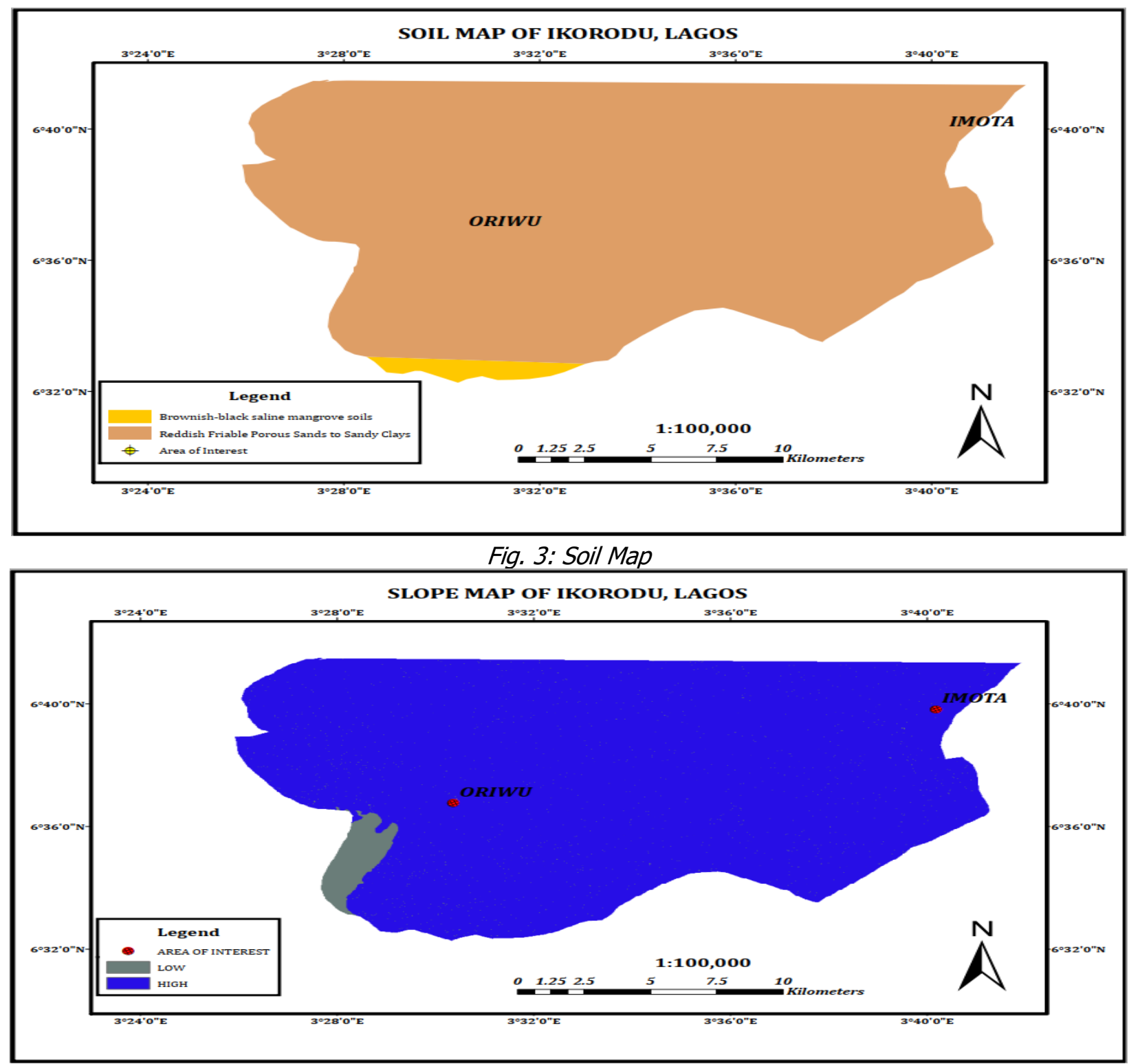

Fig. 4: Slope Map

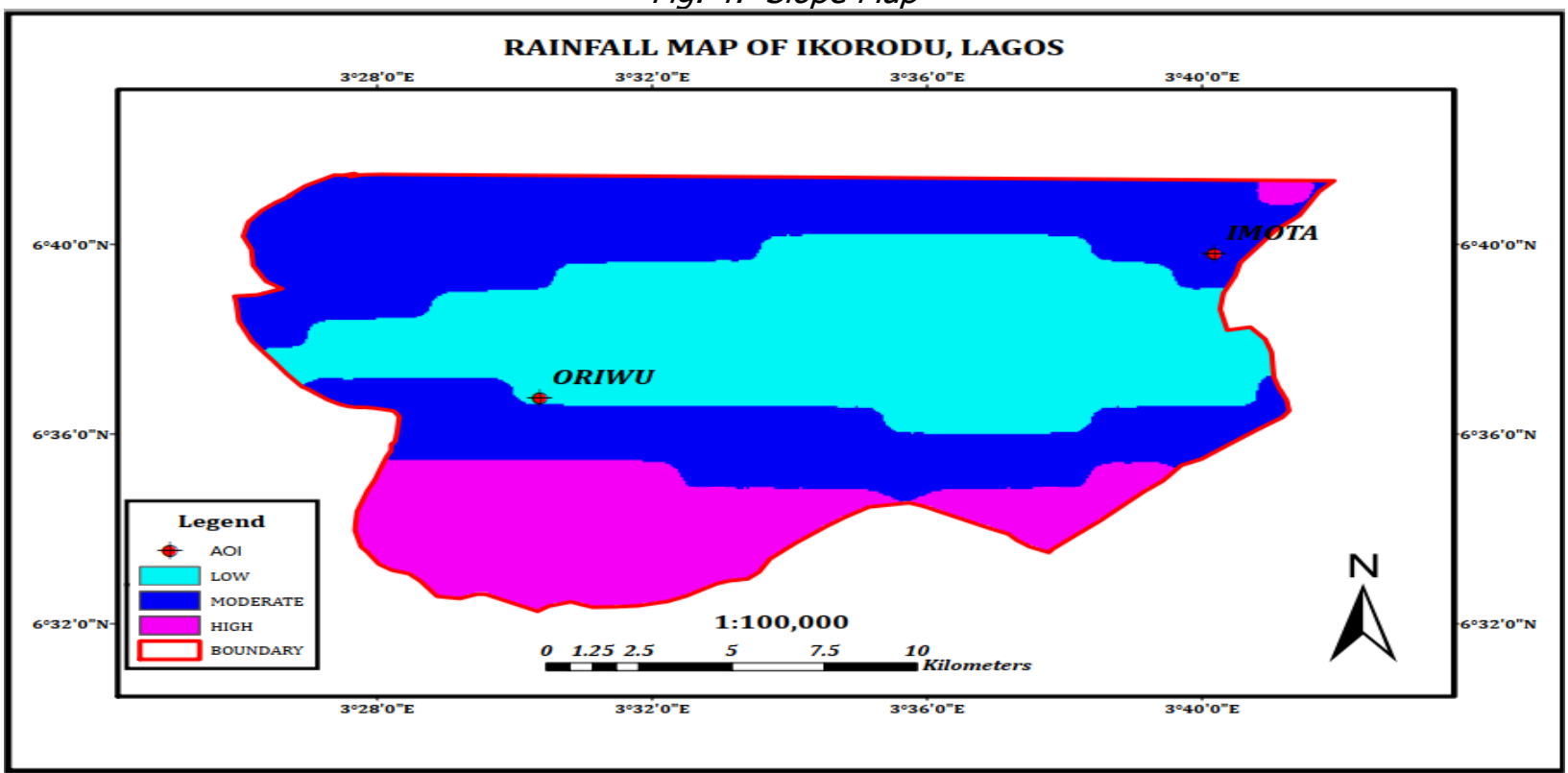

Fig. 5: Rainfall map 


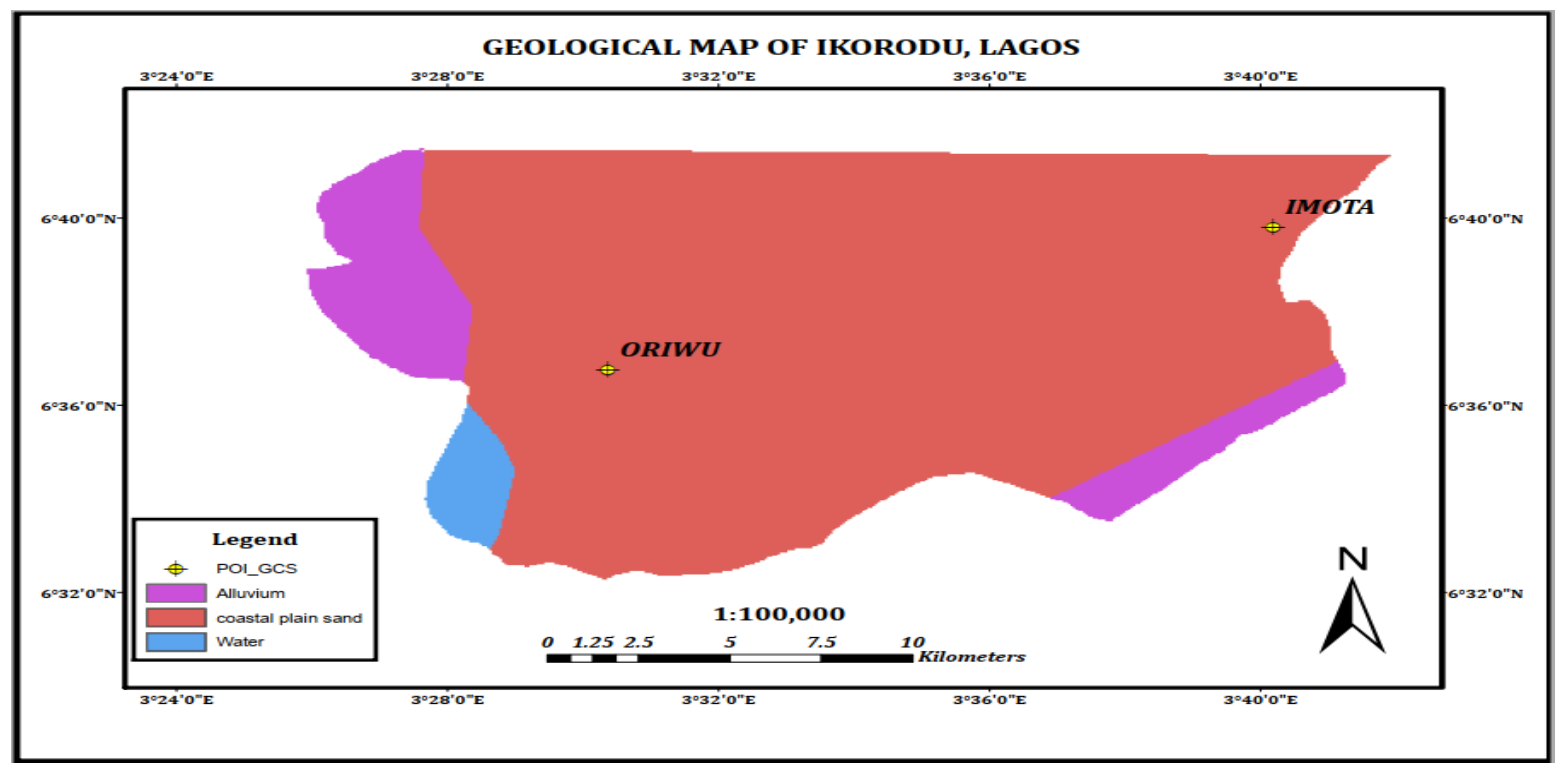

Fig. 6: Geological Map of Ikorodu
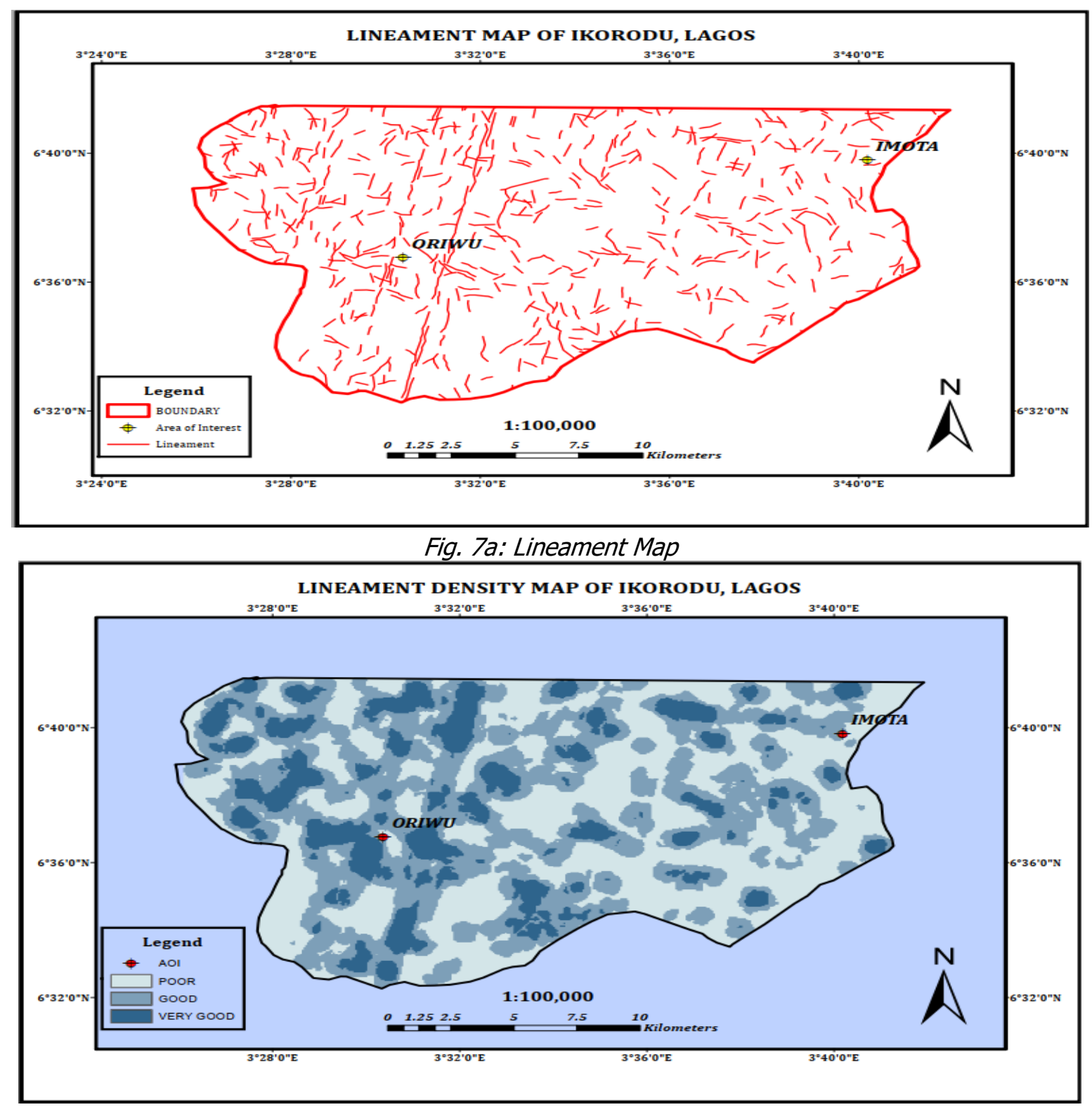

Fig. 7b: Lineament Density Map 


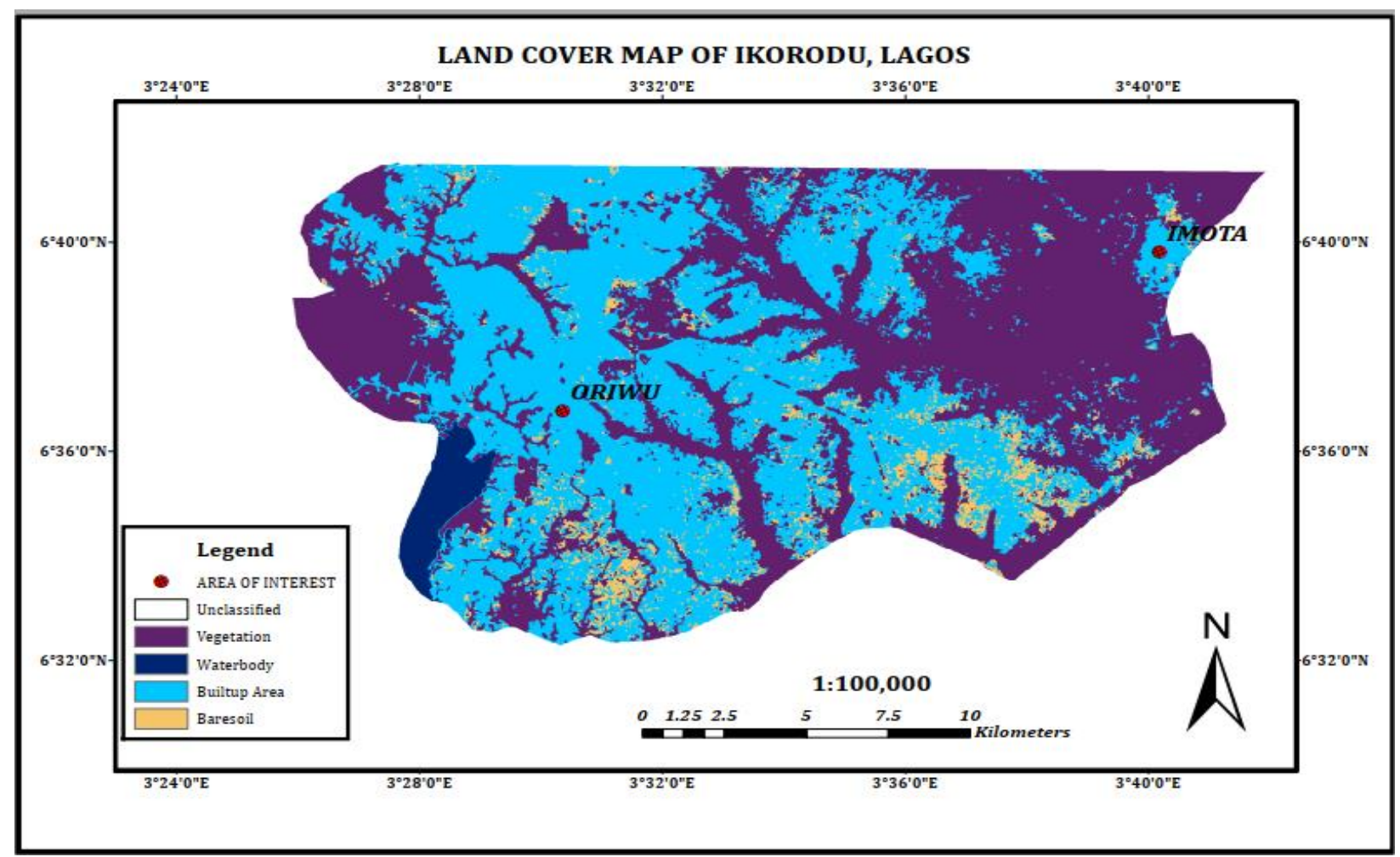

Fig. 8a: Land Cover Map

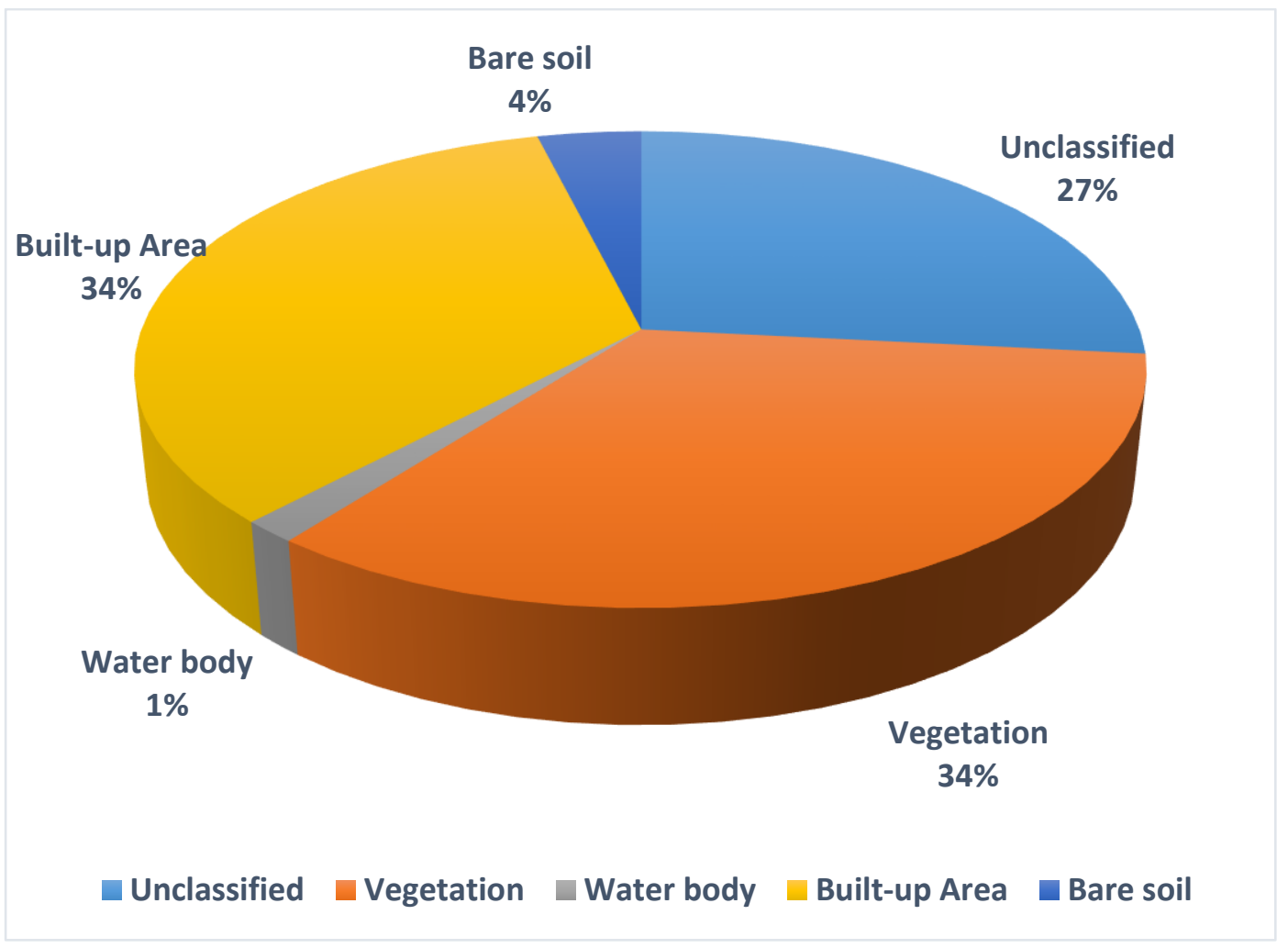

Fig.8b: Land Cover class percentage distribution 


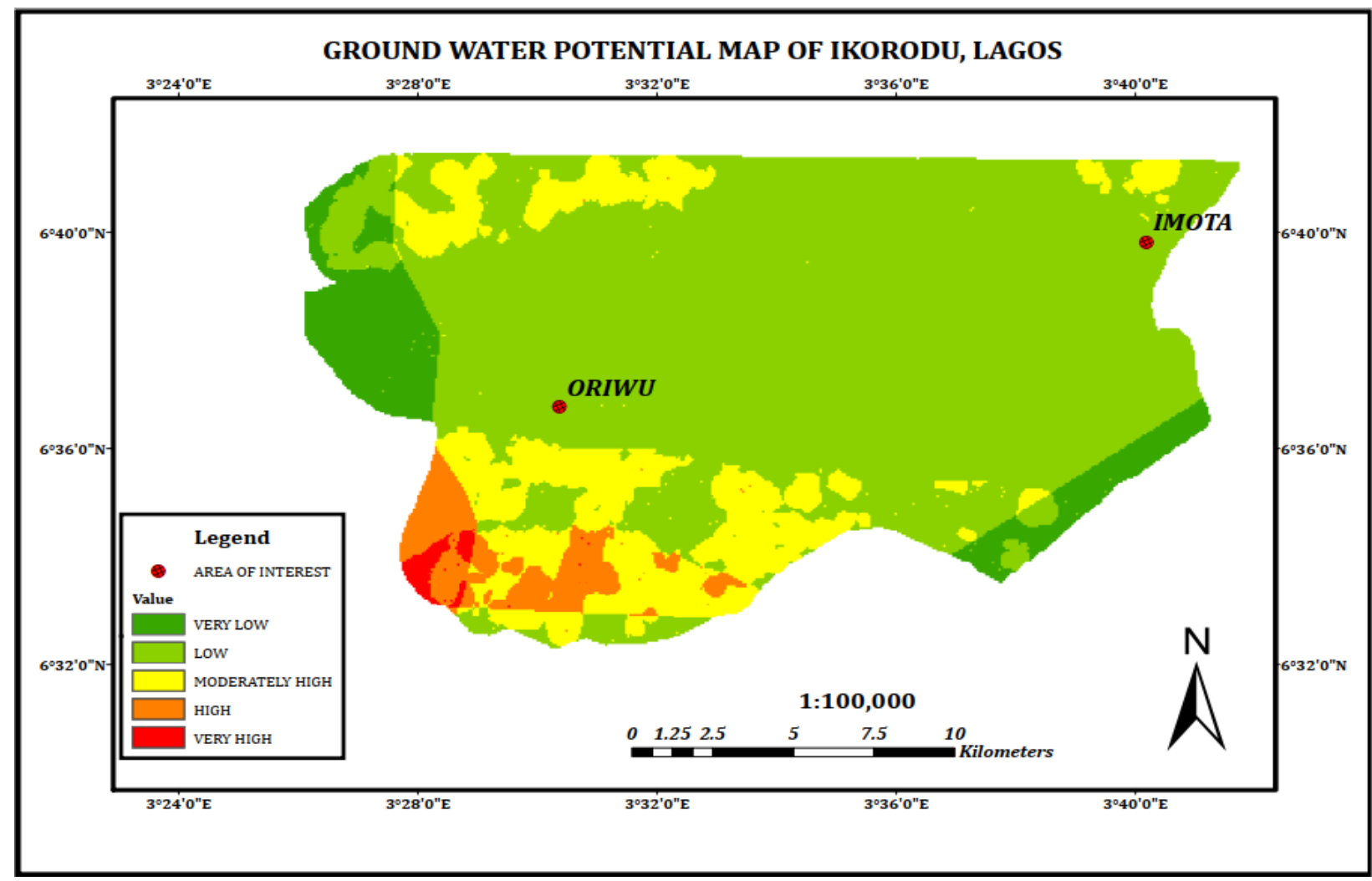

Fig. 9: Groundwater Potential Map

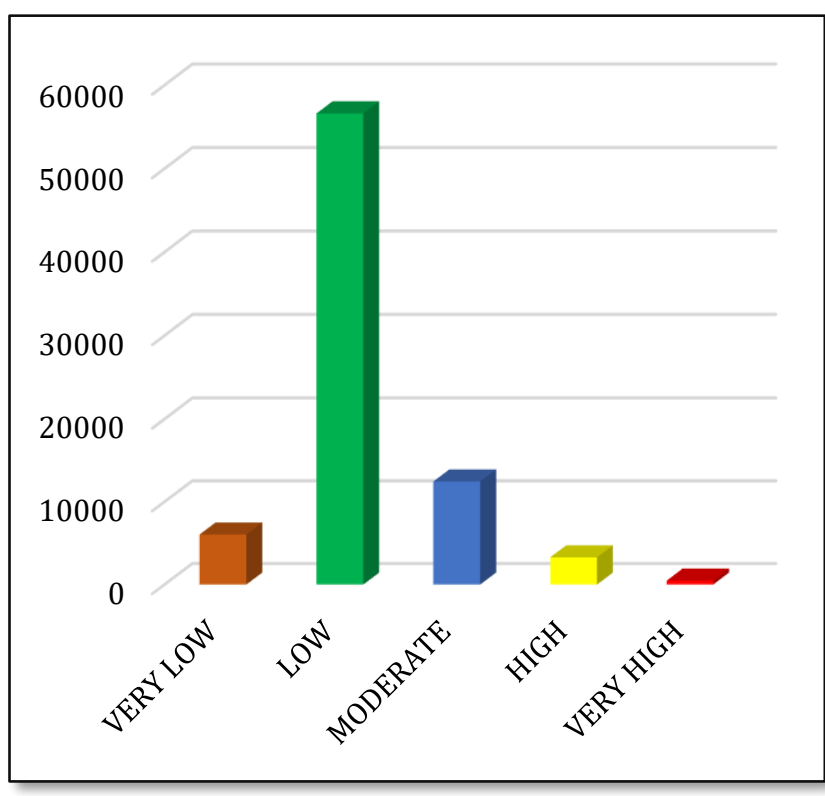

Fig. 10a: Bar Chart depicting the Groundwater Potential distribution of the study area

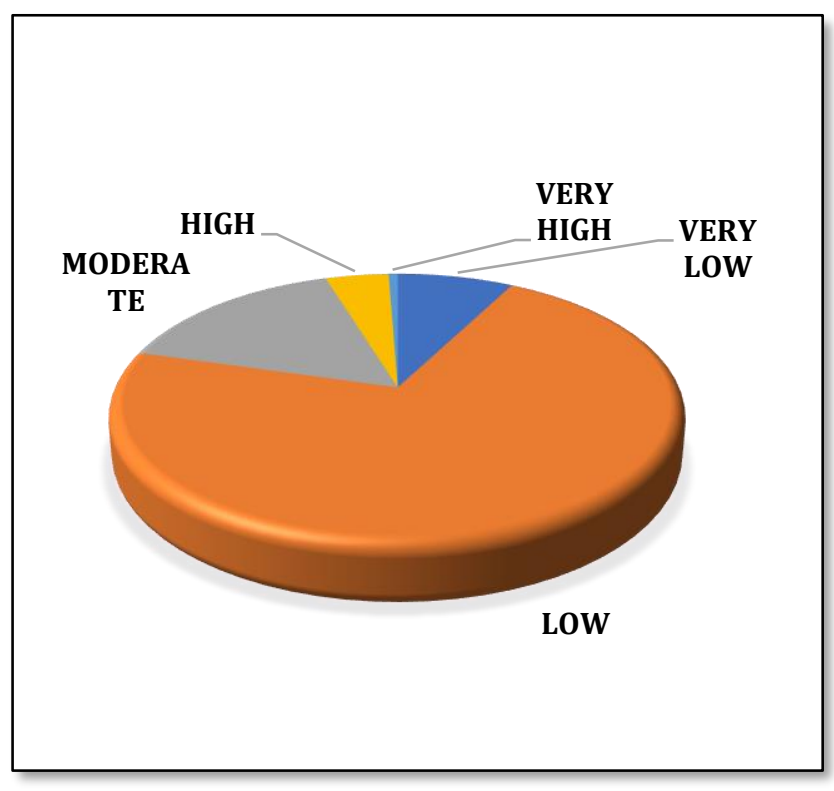

Fig. 10b: Pie Chart depicting the Groundwater Potential distribution of the study area 


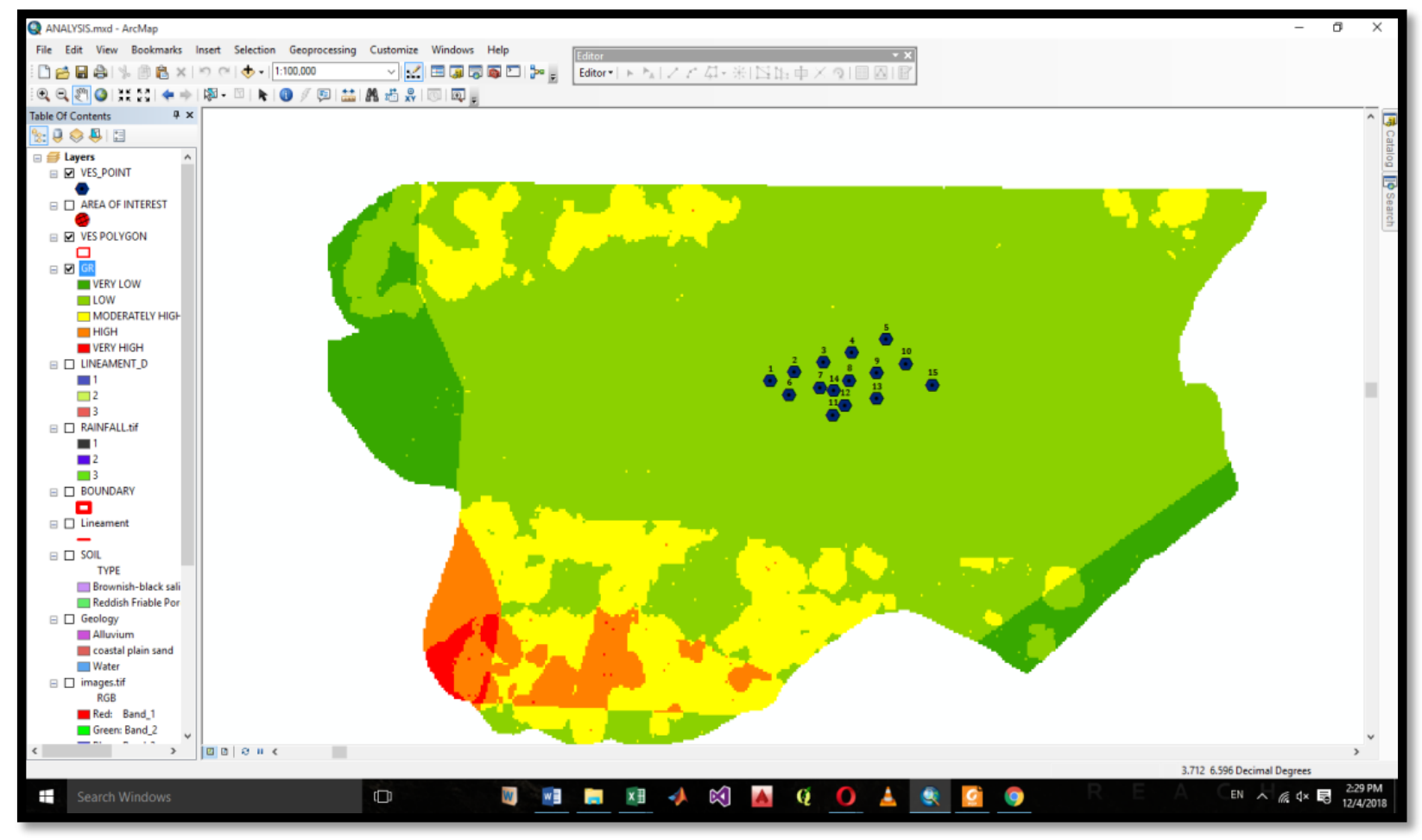

Fig. 11: VES points overlaid in the study area

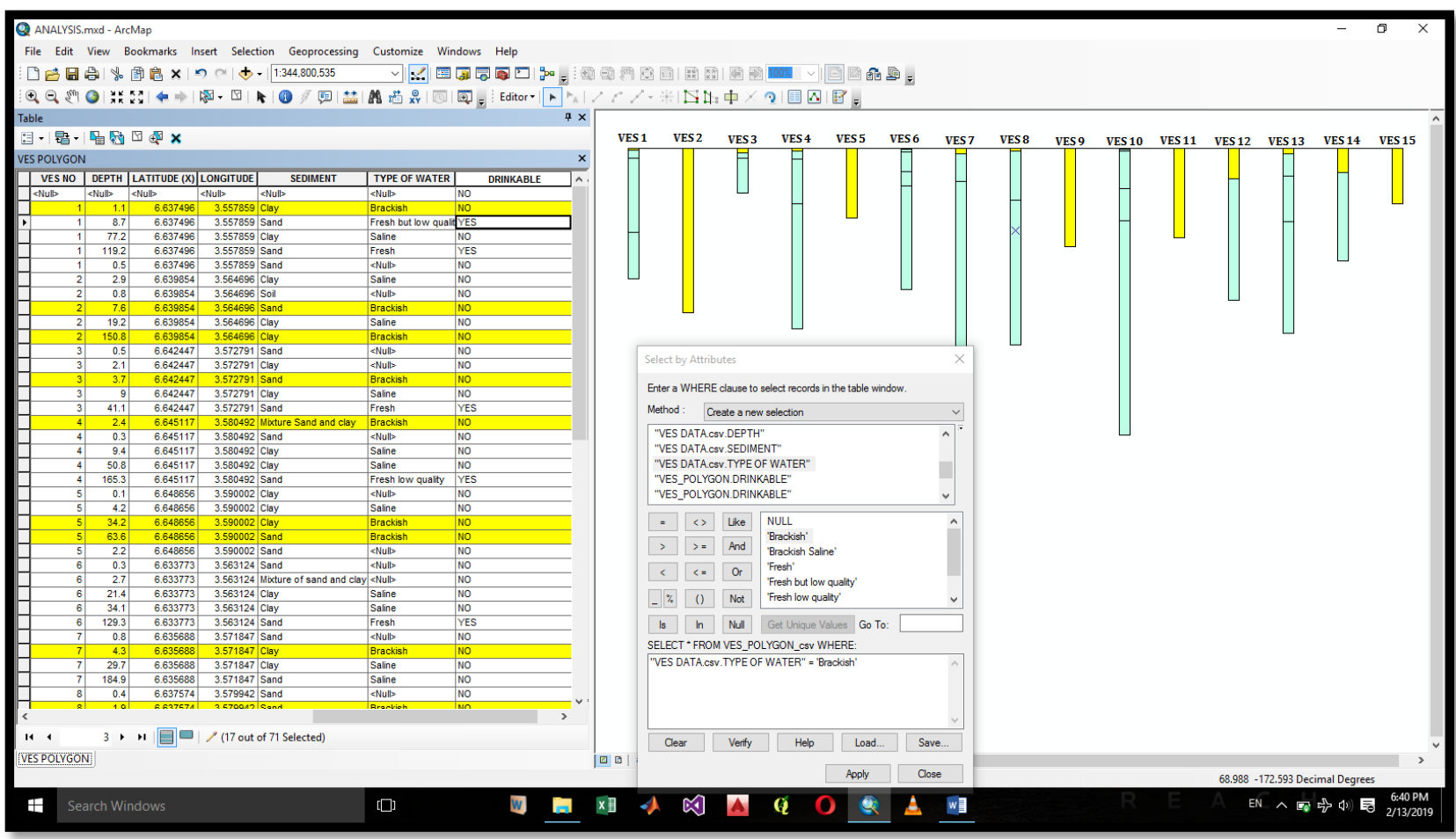

Fig. 12a: Query for Brackish water type 


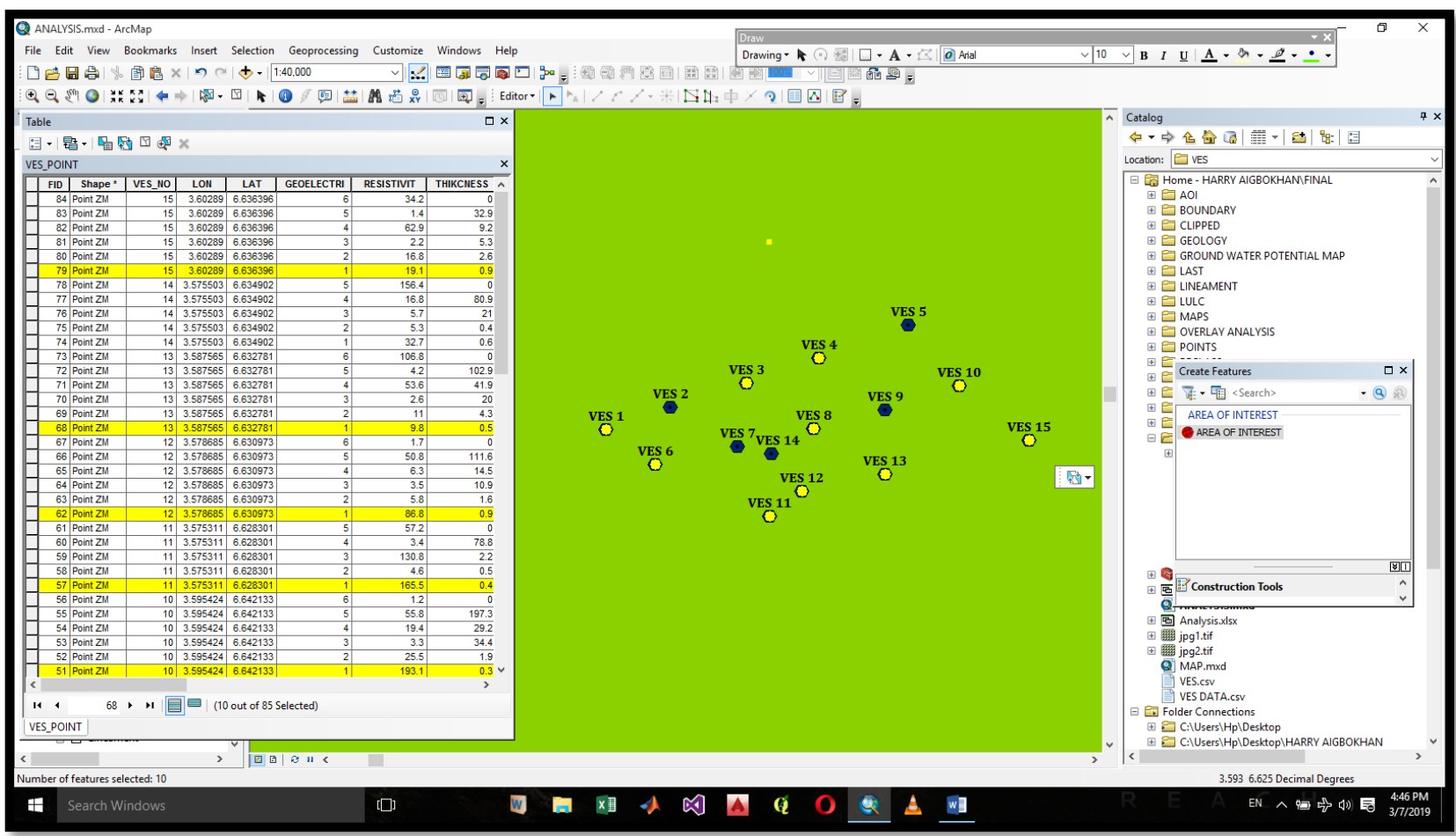

Fig. 12b: VES points on Groundwater Potential Map for QUERY 1

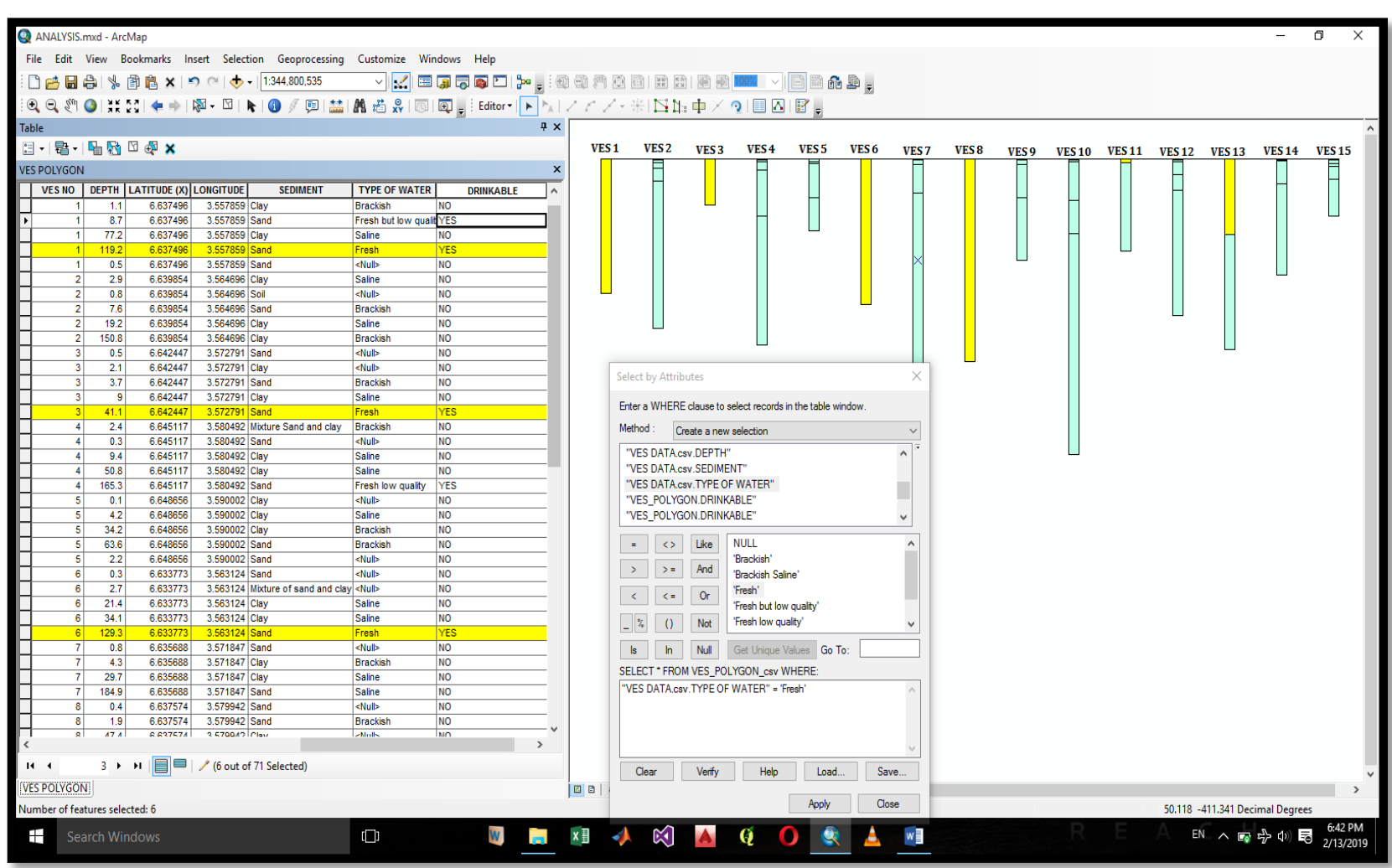

Fig. 13a: Query for Fresh water type 


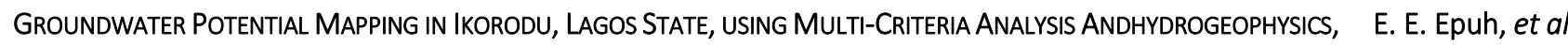

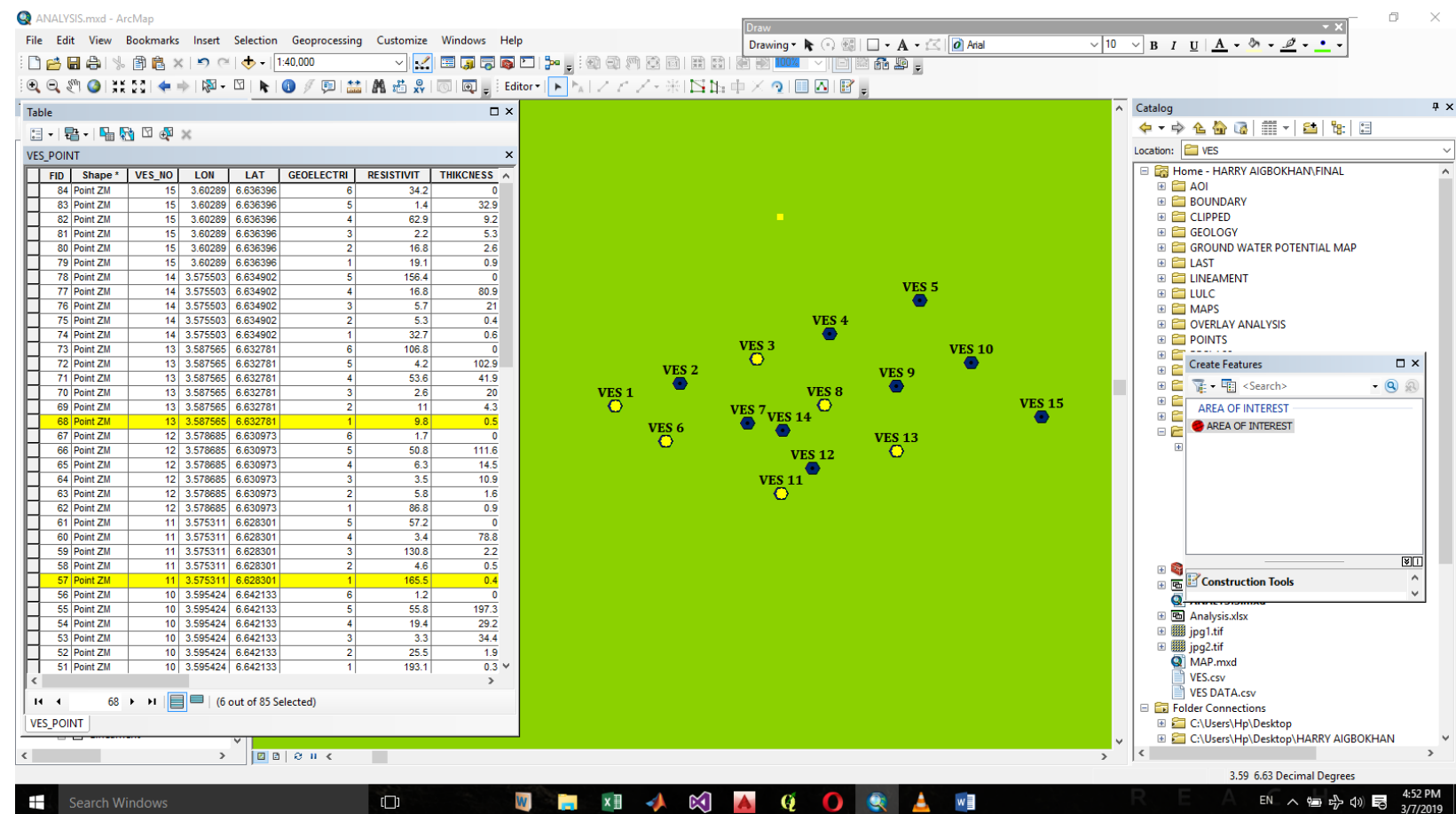

Fig. 13b: VES points on Groundwater Potential Map for QUERY 2

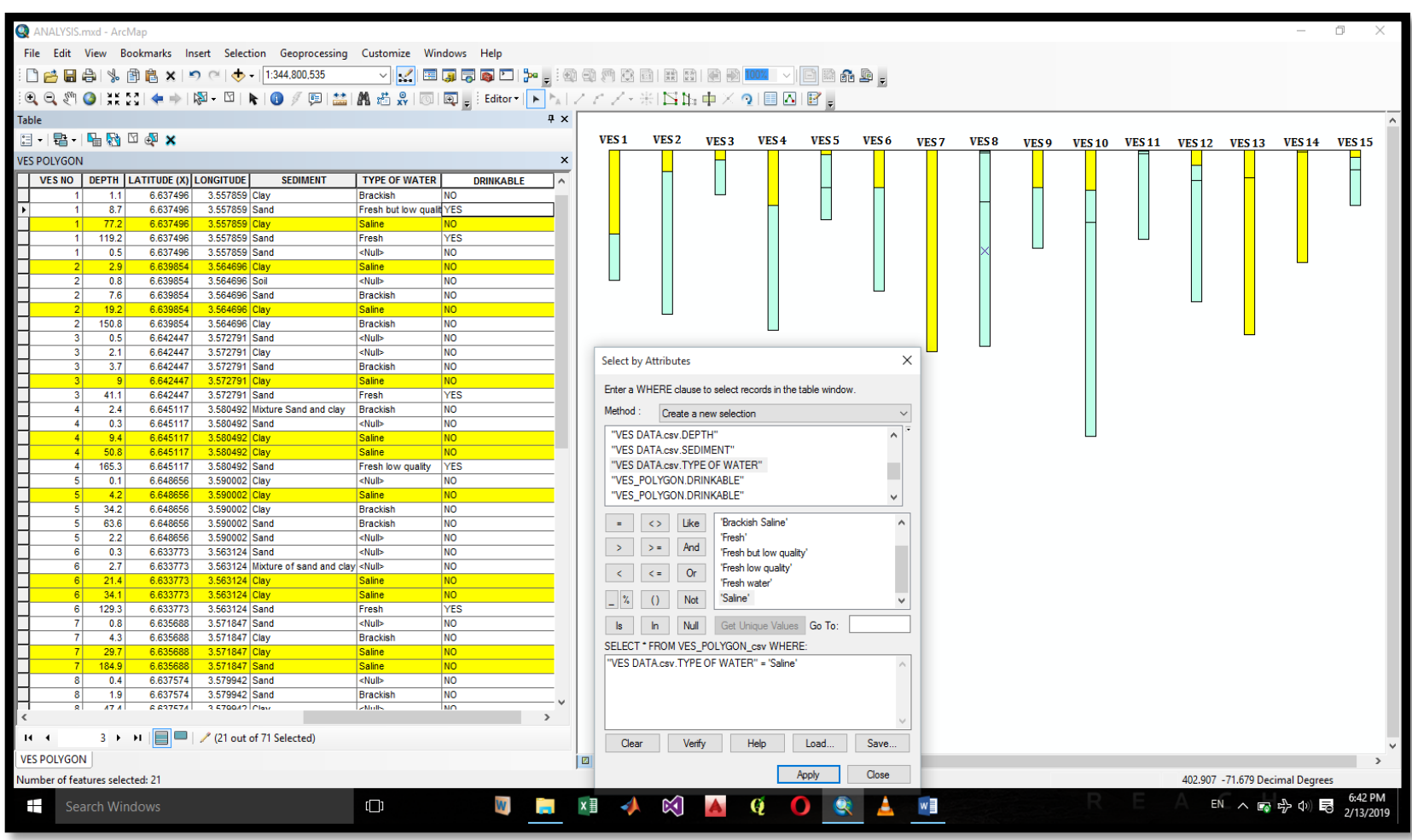

Fig. 14a: Query for Saline water type 


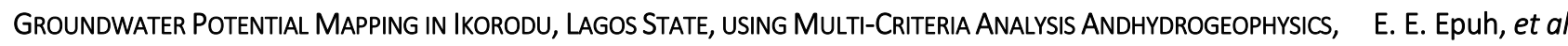

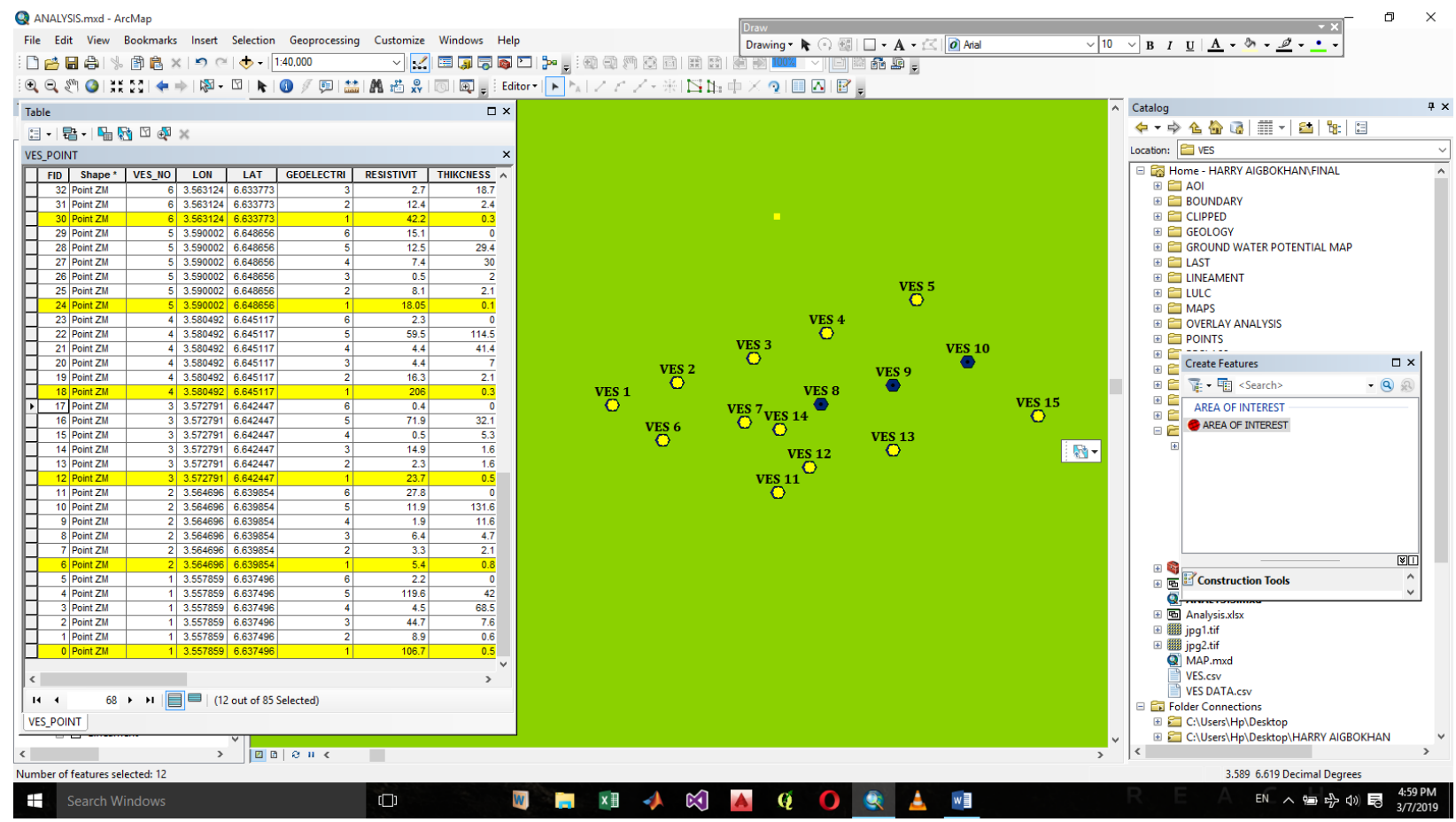

Fig. 14b: VES points on Groundwater Potential Map for QUERY 3

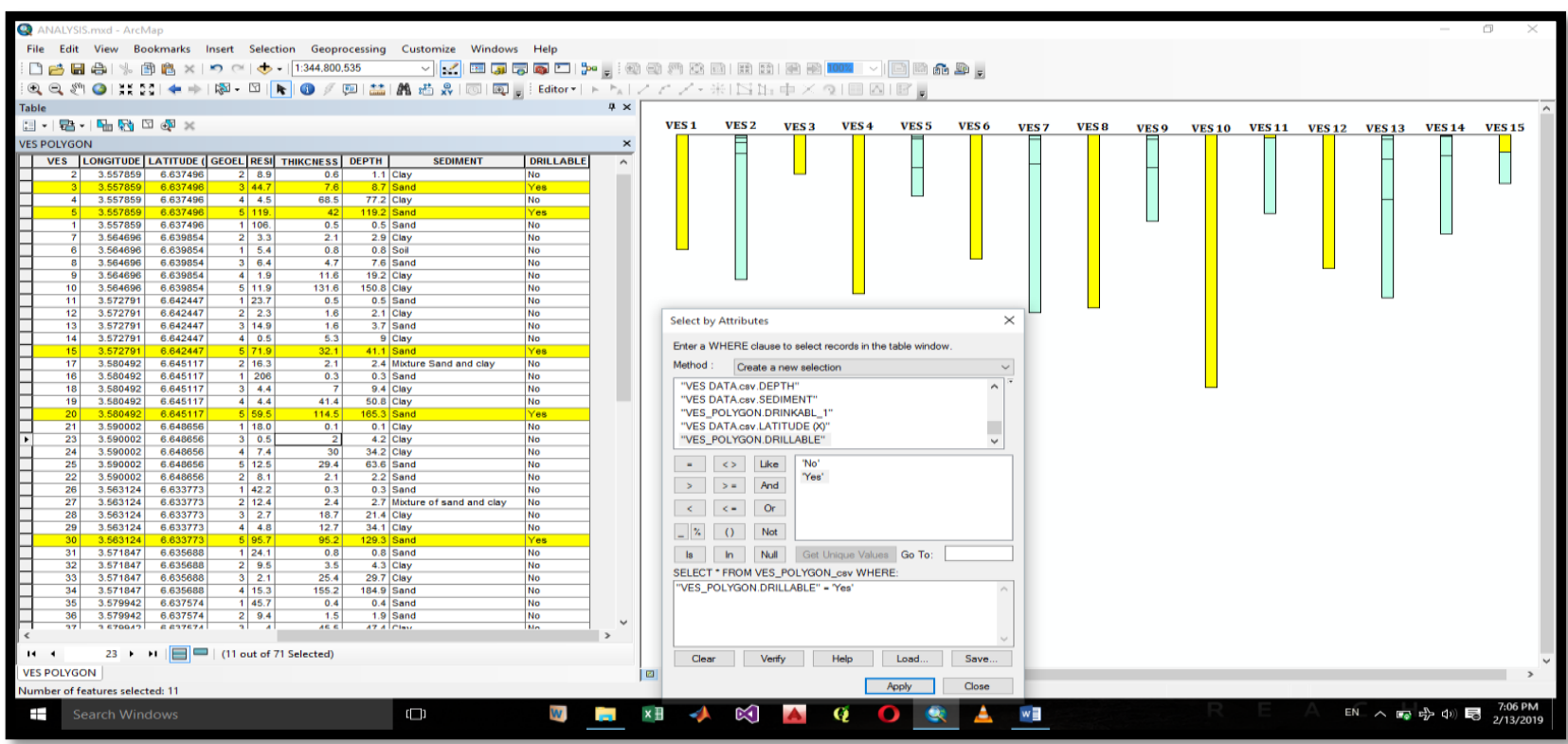

Fig. 15a: Query for Drillable locations in the study area 


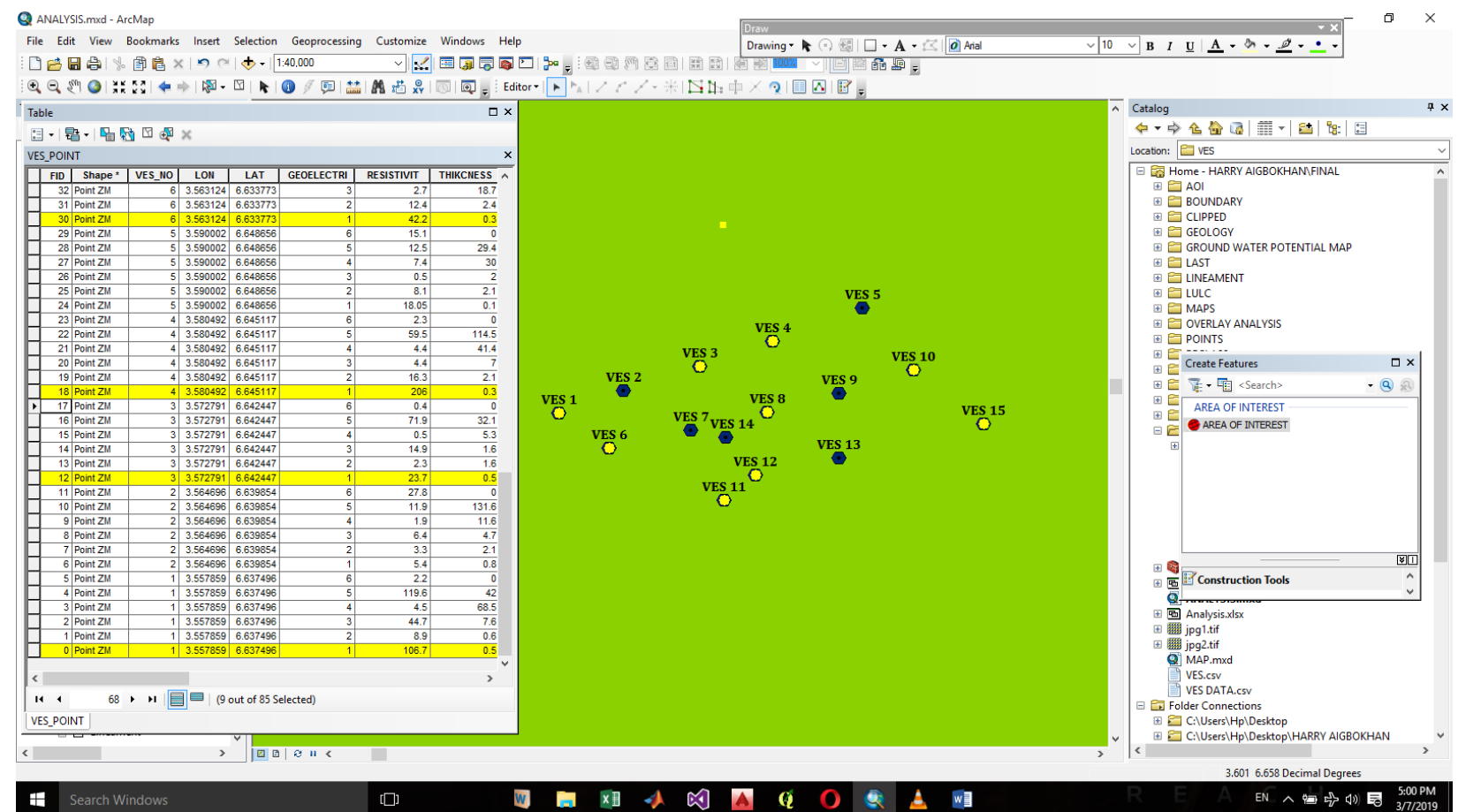

Fig. 15b: VES points on Groundwater Potential Map for QUERY 5

\subsection{Discussion}

The groundwater potential map as shown in Figures 9 and the resultant spatial distribution area and percentage (Figure 10a and 10b), have shown that $7.7 \%$ of the total area is dominated with "very low" ground water potential, $71.7 \%$ is characterized by "Low" groundwater potential, $15.8 \%$ of the region is moderately dominated by ground water, $4.2 \%$ has "high ground" water potential and $0.6 \%$ of the total area has the highest ground water potential. The South-Western region of Ikorodu, close to Oriwu has the highest concentration of groundwater. Imota is characterized with Moderate and Low ground water potentials. The very high potential areas are mainly concentrated along the River Alluvium (lower part of the study area). While the "very low" prospect is majorly where there is sand and clay.

Brackish water is a mixture of salt water and fresh water hence, not suitable for human consumption. They are found in the clay sand formations. A query on the geoelectric database shows that the following VES points: $1,3,4,6,8,10,11,12,13$, and 15 possess clay sand layers that have brackish groundwater type in them. Fresh water is any naturally occurring water except seawater and brackish water. Fresh water is generally characterized by having low concentrations of dissolved salts and other total dissolved solids. Though the term specifically excludes seawater and brackish water, it does include mineral-rich waters such as chalybeate springs. The database Query issued to check the VES geoelectric layers where fresh ground water can be found shows that VES points at various depths VES 1 $(119.2 \mathrm{~m})$, VES $3(41.1 \mathrm{~m})$, VES $6(129.3 \mathrm{~m})$, VES 8 $(180.4 \mathrm{~m}), \operatorname{VES} 11(3.1 \mathrm{~m})$, and VES $13(66.7 \mathrm{~m})$ have some geoelectric layers that possess Fresh groundwater. Saline water (more commonly known as salt water) is water that contains a high concentration of dissolved salts (mainly $\mathrm{NaCl}$ ). The database Query issued to check the VES geoelectric layers where Saline ground water can be found shows that VES points $1,2,3,4,5,6,7,11,12,13,14$, and 15 have some geoelectric layers that possess Saline groundwater. Another Query was carried out to determine the Areas which are drillable around the VES locations. The criteria used for this was Fresh water type. VES points $1,3,4,6,8,10,11,12$ and 15 falls in this category.

\section{CONCLUSION}

Integration of Remote Sensing, GIS and Hydrogeophysics for the delineation of ground water potential zones has proven to be very efficient, cost effective, time saving and requires less labor. The most probable groundwater potential zone was found in the southwestern part of the study area due to the presence of fractures, swamps with high infiltration capacity and the presence of water bodies which is 
primarily responsible for recharging groundwater in any area.

The results of this study can serve as guideline for planning future artificial recharge projects in the study area to ensure sustainable ground water utilization. In a developing area like Ikorodu, findings from this study can be used by policy makers for good decision making. The result of this study shows that the depth range for drillable aquifer is between $20 \mathrm{~m}$ and $120 \mathrm{~m}$ and this can serve as guidelines in determining the depth for drilling wells within the study area. From the query results, aquiferous layers have been identified, their yield and potentials have been known and the depths to which boreholes can be sunk have been determined. Hence, this integrated approach of ground water potential assessment using remote sensing and GIS is highly recommended

\section{REFERENCES}

[1]. Al-Garni, M. A. (2009). Geophysical investigations for groundwater in a complex subsurface terrain, Wadi Fatima, KSA: A case history. Jordan Journal of Civil Engineering, 3(2), 118-136.

[2]. VenkataRao, G., Kalpana, P. and Rao, R. S. (2014). Groundwater investigation using geophysical methods-a case study of Pydibhimavaram Industrial area. International Journal of Research in Engineering and Technology, 3(16), 13-17.

[3]. Singhal, B. and Gupta, B. (1966). Analysis of pumping test data from a well in the IndoGangetic alluvium of India and its bearing on the aquifer characteristics. Journal of Hydrology, 4, 121-140.

[4]. Epuh, E. E., Sanni, K. A., \& Orji, M. J. (2019). Application of Remote Sensing, GIS and Hydrogeophysics to Groundwater Exploration in Lagos Metropolis: A case study of Oshodi/Isolo LGA. Nigerian Journal of Environmental Sciences and Technology (NIJEST). 3(1), 41-45.
[5]. Reddy, G. O., Mouli, K. C., Srivastav, S., Srinivas, C. and Maji, A. (2000). Evaluation of ground water potential zones using remote sensing data-A case study of Gaimukh watershed, Bhandara District, Maharashtra. Journal of the Indian Society of Remote Sensing, 28(1), 19.

[6]. Greenbaum, D. (1987). Lineament Studies in Masvingo Province, Zimbabwe.

[7]. Greenbaum, D. (1992). Structural influences on the occurrence of groundwater in SE Zimbabwe. Geological Society, London, Special Publications, 66(1), 77-85.

[8]. Mabee, S. B., Hardcastle, K. C. and Wise, D. U. (1994). A method of collecting and analyzing lineaments for regional-scale fracturedbedrock aquifer studies. Groundwater, 32(6), 884-894.

[9]. Sander, P., Chesley, M. M. and Minor, T. B. (1996). Groundwater assessment using remote sensing and GIS in a rural groundwater project in Ghana: lessons learned. Hydrogeology Journal, 4(3), 40-49.

[10]. Koch, M., \& Mather, P. (1997). Lineament mapping for groundwater resource assessment: a comparison of digital Synthetic Aperture Radar (SAR) imagery and stereoscopic Large Format Camera (LFC) photographs in the Red Sea Hills, Sudan. International Journal of Remote Sensing, 18(7), 1465-1482.

[11]. Hill, M. and Webb, J. (1958). The ecology of Lagos lagoon II. The topography and physical features of Lagos harbour and Lagos lagoon. Philosophical Transactions of the Royal Society of London. Series B, Biological Sciences, 241(683), 319-333.

[12]. Longe, E., Malomo, S. and Olorunniwo, M. (1987). Hydrogeology of Lagos metropolis. Journal of African Earth Sciences (1983), 6(2), 163-174.

[13]. Jones, H., and Hockey, R. (1964). The geology of part of South-western Nigeria Geol. Survey Niger. Bull, 31, 1-101. 